\title{
What Differentiates Method Stoppers from Switchers? Contraceptive Discontinuation and Switching Among Honduran Women
}

By Janine BardenO'Fallon and Ilene Speizer

Janine BardenO'Fallon is director, MEASURE Evaluation Population E Reproductive Health, Carolina Population

Center, University of North Carolina, Chapel Hill, NC, USA. Ilene Speizer is research associate professor, Department of Maternal and Child Health, University of North Carolina

Gillings School of Global Public Health, Chapel Hill.
CONTEXT: Contraceptive discontinuation contributes to unplanned pregnancy and unwanted births, as well as increased maternal, neonatal and infant morbidity and mortality. Information on differences between women who stop using contraceptives and those who switch to another method would be useful for programs aimed at preventing unplanned pregnancies and their consequences.

METHODS: Data come from two rounds of interviews with women aged 15-44 (800 interviewed at baseline and 671 reinterviewed one year later) who were new or continuing users of injectable or oral contraceptives or an IUD. Bivariate analysis examined associations between attitudes and behaviors of women who discontinued their baseline method and side effects they experienced. Multivariate logistic regression assessed differences between women who switched methods immediately or within one month of discontinuation and those who stopped contraceptive use for one month or more.

RESULTS: Of the 671 women who were reinterviewed, $41 \%$ (273) discontinued use of their baseline contraceptive method within the one-year follow-up; of those, $43 \%$ (117) switched to a new method, and 57\% (156) stopped for one month or more. Seeking help with side effects from a health worker, urban residence, talking to a partner about the decision to discontinue, and new and recent method adoption were associated with increased odds of switching methods (odds ratios, 2.0-3.5).

CONCLUSION: Access to high-quality family planning services and encouraging discussion with partners and families before stopping contraceptive use is important for women who experience side effects from contraceptive methods and are at risk of discontinuation.

International Perspectives on Sexual and Reproductive Health, 2011,37 (1):16-23, doi:10.1363/3701611
Contraceptive discontinuation-ceasing to use one's current method of contraception-is common, though rates vary widely by country. According to Demographic and Health Survey (DHS) data from 18 countries, 20-50\% of users of reversible modern methods of contraception discontinued their method during the first 12 months of use. ${ }^{1}$ In a 2009 study of DHS data from eight countries, the 12-month discontinuation rate ranged from $18 \%$ to $49 \%{ }^{2}$ Contraceptive discontinuation can be active, as it is when a woman must visit a clinic to have her IUD removed, or passive, requiring no extra effort, as it is when a woman misses an appointment for a reinjection or forgets to refill her prescription for birth control pills. Data from a wide range of countries show that contraceptive methods that can be passively discontinued, such as oral contraceptives, condoms, injectables and traditional methods, have higher rates of discontinuation than methods requiring active discontinuation, such as the IUD and implants. ${ }^{2-6}$

Not all women who discontinue a contraceptive method become nonusers; some switch to another, more (or less) effective method. However, women who want to avoid pregnancy but discontinue contraceptive use without switching to a new method are at risk for unplanned pregnancies and unwanted or mistimed births, which can lead to maternal, neonatal and infant morbidity and mortality. ${ }^{7-9}$ High rates of stopping may indicate missed opportunities to promote and sustain contraceptive use, ${ }^{10,11}$ and, therefore, can be a measure of family planning service quality. High-quality services that provide a range of contraceptive methods and offer counseling can increase the likelihood that women will switch rather than discontinue use altogether. ${ }^{12,13}$ A 2010 study of oral contraceptive discontinuation and switching behavior in 19 countries found that, on average, $35 \%$ of women who discontinued contraceptive use because of method dissatisfaction switched to another method within three months, leading the authors to suggest that more attention should be paid to the issue of method switching as opposed to simply method discontinuation. ${ }^{3}$

Whether a woman discontinues use of one method and switches to another or stops practicing contraception altogether depends on several factors. For example, women who stop using one method are not likely to switch or reinitiate use if they are not with a partner (because of divorce, separation or death of a spouse), can no longer become pregnant (are infecund) or want to become pregnant. Research has estimated that reduced need accounts for $7-20 \%$ of discontinuation of all reversible methods. ${ }^{13}$ 
Other factors include age, parity and union status, each of which is associated with discontinuation more consistently than are education, area of residence or household income. ${ }^{5,14}$ However, urban women and women with higher levels of education and socioeconomic status are more likely to switch than stop after discontinuing a method, whereas older age is related to a decreased likelihood of switching. 5,6 Side effects and health concerns are among the most common reasons women give for discontinuing a method. ${ }^{1,14}$ Though experiencing side effects increases the likelihood of method discontinuation, ${ }^{15,16}$ it is not known if it is associated with a woman's decision to switch to another method.

Research on service quality and contraceptive discontinuation has produced mixed results. ${ }^{11,17-21}$ Few studies have looked specifically at service quality and method switching; but, according to a 2005 study of switching behaviors in Bangladesh, women who had more contacts with family planning outreach workers were less likely to discontinue a method or stop use altogether than women who had fewer such contacts. ${ }^{22}$ Furthermore, although method characteristics influence discontinuation, they would not be expected to inhibit switching behavior, as long as other types of contraceptive methods are accessible. In research from Morocco, for example, women who lived near facilities that offered three or more methods were more likely to switch than were women who lived near facilities that offered fewer method choices. ${ }^{19}$

The goal of this analysis is to examine the differences between women who resumed contraceptive use shortly after discontinuing a method and women who stopped practicing contraception for at least one month before beginning another method or stopped altogether. We assess factors identified by previous studies as related to contraceptive use and discontinuation; these include demographic characteristics, fertility desires, perceived service quality, and experience with the discontinued method and its side effects. We also collected information on women's contraceptive decision making and include variables related to the degree of engagement with their partner, family and friends in discussing family planning methods and decisions to discontinue. We aim to compare method switchers with stoppers and to use the results to identify programmatic implications.

The study uses data from Honduras, a small Central American country with a population of approximately 7.3 million people. The prevalence of modern contraceptive use is relatively high in Honduras: $56 \%$ among married women aged $15-49 .{ }^{23}$ Female sterilization is the most commonly used modern method (21\%), followed by the reversible methods of interest in this study: injectables (14\%), birth control pills (11\%) and the IUD (7\%). ${ }^{23}$ The public sector-the Secretary of Health system of hospitals, health centers with doctors and dentists (CESAMOs), and rural health clinics staffed by nurses (CESARs)-supplies contraceptive services to $44 \%$ of the country's family planning users. The Honduran Family Planning Association (commonly known as ASHONPLAFA), the local International Planned Parenthood Federation affiliate, is the country's main private provider of family planning services, serving 25\% of all users. Pharmacies, which provide contraceptives to $13 \%$ of users overall, are the most common provider of birth control pills, supplying $35 \%$ of pill users nationwide. Additional providers of contraceptive services include other private clinics and hospitals (9\%) and hospitals of the Honduran Institute of Social Services (5\%).

\section{METHODS}

\section{Data}

The data for this analysis come from a panel study on the determinants of contraceptive discontinuation conducted in four urban areas of Honduras: Tegucigalpa, San Pedro Sula, Santa Rosa de Copán/La Entrada and Gracias. The data were collected in two rounds: First, we administered a baseline survey questionnaire between October and November 2006; we conducted a follow-up survey one year later. The baseline data were collected from exit interviews with women who received the injectable, birth control pills or an IUD during a family planning appointment at one of 13 selected health facilities, which included seven CESAMOs, one Secretary of Health hospital and five ASHONPLAFA clinics. Eligible women were aged 15-44. They were either new or continuing users of one of the three reversible methods. No enrollment quotas by method type were required. All eligible, consenting women were interviewed until a total of 200 interviews were obtained from each of the four urban areas. Overall, 800 interviews were completed.

Follow-up data were collected between October and December 2007 from 84\% (671) of the women who had participated at baseline. Interviewers used contact information provided by the respondents at baseline to locate the women and arrange for the follow-up interviews.

The baseline survey questionnaire collected information on demographic characteristics, birth histories, previous contraceptive use, perception of service quality at clinic appointment, motivation to avoid pregnancy and the family planning decision-making environment. The follow-up questionnaire collected information on contraceptive use for each month since the baseline interview (using a contraceptive calendar); experience of and reaction to side effects during the 12-month follow-up; and updates on demographics, fertility motivations and the decision-making environment.

Authorization for the study was obtained from the Institutional Review Board (IRB) of the University of North Carolina at Chapel Hill, the Honduran Secretary of Health and ASHONPLAFA. Written consent was obtained from each participant at baseline and follow-up.

\section{Variables}

The data on discontinuation behavior were extracted from the modified DHS monthly contraceptive calendars of the 273 women who discontinued their baseline method dur- 
TABLE 1. Percentage distribution of women who continued or stopped using the IUD, the injectable or birth control pills received during a family planning appointment at a health facility in urban Honduras, by selected characteristics, 2006-2007

\begin{tabular}{lll} 
Characteristic & $\begin{array}{l}\text { Continued } \\
(\mathrm{N}=398)\end{array}$ & $\begin{array}{l}\text { Discontinued } \\
(\mathrm{N}=273)\end{array}$ \\
\hline Age & & \\
$15-24$ & 45.5 & 49.5 \\
$25-34$ & 46.0 & 43.2 \\
$35-44$ & 8.5 & 7.3
\end{tabular}

Education

None

Primary

$\geq$ secondary

No. of children ever born

$0-1$

$2-3$

$\geq 4$

Union status**

Married or in union

Not in union

Residence

Rural

Urban

Monthly household income

Lower

Middle

Higher

Length of method use

at baselinet

$>1$ year

$\leq 1$ year

New to method

20.9

Method used at baseline*

IUD

Injectable

Pill

Total

100.0

$\begin{array}{rr}25.4 & 14.3 \\ 68.8 & 77.7 \\ 5.8 & 8.1 \\ & \\ 100.0 & 100.0\end{array}$

${ }^{*} \mathrm{p}<.05 .{ }^{* *} \mathrm{p}<$.01. $\mathrm{tp}<0.1$. Notes: All measures except union status and residence were assessed at baseline.

ing the study period. Women were considered switchers if they began a method within a month of discontinuing the baseline method. They were considered stoppers if they did not use any other method during the follow-up period or resumed use of the same or another method after at least one month of nonuse. The dependent variable is coded " 1 " for switching and "0" for stopping with an episode of nonuse.

Independent variables included demographic characteristics, fertility desires, service quality, method characteristics, the experience of and reaction to side effects, communication with others about side effects and main reason for discontinuation.

At the baseline interview, women were asked to respond yes or no to the following questions about the quality of counseling and service provision during their appointment: Had all their questions been answered by a provider? Had they received information on how to use their contraceptive method effectively? Had they received information on the advantages and disadvantages of their method? Had they ever been informed of side effects of their method? Several questions about women's clinic appointment experiences (their level of satisfaction with a clinic's cleanliness, degree of privacy, quality of provider treatment and care) were omitted from the study because responses produced little variation (fewer than $10 \%$ were negative).

At follow-up, women were asked to respond yes, no or no side effect to the following questions about their experience of side effects during the study period: Had they had any side effects? Had they had two or more side effects? Had their side effects included abdominal pain, amenorrhea, dizziness, facial spotting, heavy bleeding, infections, irregular bleeding, nausea or vomiting, weight gain or weight loss? Although the women mentioned some or all of these side effects, at least 50 women each mentioned headaches, amenorrhea and heavy bleeding, the side effects selected for inclusion in the analysis. Women who experienced no side effects were included in the reference category of women who responded no when asked about specific side effects.

\section{Analysis}

A cross-tabulation was constructed to compare the characteristics of women who switched methods to those of women who stopped use for at least one month. Pearson's chi-square test was used to identify associations between the dependent variable and each independent variable. Independent variables associated with the dependent variable with at least a 90\% degree of significance were considered for the multivariate analysis.

A further descriptive analysis was conducted among women who discontinued their baseline method because of headaches, amenorrhea or heavy bleeding. The analysis compared the attitudes and behaviors of women who switched to another method with those of women who stopped practicing contraception for at least one month, by side effect. The analysis included only the most commonly experienced side effects (headaches, amenorrhea and heavy bleeding). Pearson's chi-square test was used to identify significant differences between groups in their reactions to specific side effects.

A multivariate logistic regression was conducted to identify differences between women who switched methods and women who stopped and did not resume use of any method for a least one month. Before building the multivariate model, we used Spearman's p to identify associations between predictor variables. Correlations between predictor variables were assessed before running the regression. In any pair of variables with a correlation greater than $+/-0.6$, we eliminated one from the model. Union status was captured in the null categories for partner variables. Women not experiencing side effects were part of null categories. All analyses were run using STATA version 10.1. 
TABLE 2. Percentage distributions and percentages of women by contraceptive use status after discontinuation of baseline method, by selected characteristics, Honduras, 2006-2007

\begin{tabular}{|c|c|c|c|c|c|}
\hline Characteristic & $\begin{array}{l}\text { Switched } \\
(\mathrm{N}=117)\end{array}$ & $\begin{array}{l}\text { Stopped } \\
(N=156)\end{array}$ & Characteristic & $\begin{array}{l}\text { Switched } \\
(N=117)\end{array}$ & $\begin{array}{l}\text { Stopped } \\
(\mathrm{N}=156)\end{array}$ \\
\hline \multicolumn{3}{|l|}{$\begin{array}{l}\text { PERCENTAGE DISTRIBUTIONS } \\
\text { Age* }\end{array}$} & \multicolumn{3}{|l|}{$\begin{array}{l}\text { Discussed discontinuing baseline method } \\
\text { with partner before doing so** }\end{array}$} \\
\hline $15-24$ & 58.1 & 43.0 & Yes & 86.3 & 60.3 \\
\hline $25-34$ & 37.6 & 47.4 & No & 13.7 & 39.7 \\
\hline \multirow[t]{2}{*}{$35-44$} & 4.3 & 9.6 & & & \\
\hline & & & $\begin{array}{l}\text { Main reason for discontinuation } \\
\text { of baseline method } \neq, * *\end{array}$ & & \\
\hline None & 3.4 & 7.0 & Reduced need & 3.5 & 44.9 \\
\hline Primary & 57.3 & 68.6 & Problems with method & 87.7 & 48.7 \\
\hline$\geq$ secondary & 39.3 & 24.4 & Other & 8.8 & 6.4 \\
\hline \multicolumn{3}{|l|}{ No. of children ever born* } & Total & 100.0 & 100.0 \\
\hline $0-1$ & 54.7 & 42.3 & & & \\
\hline$\geq 2$ & 45.3 & 57.7 & $\begin{array}{l}\text { PERCENTAGES } \\
\text { Service quality }\end{array}$ & & \\
\hline Union status* & & & Provider answered all questions** & 72.7 & 50.0 \\
\hline In union & 89.7 & 80.1 & Informed about effective method use & 52.1 & 43.6 \\
\hline Not in union & 10.3 & 19.9 & $\begin{array}{l}\text { Informed about advantages and } \\
\text { disadvantages of methodt }\end{array}$ & 44.4 & 34.6 \\
\hline Residence** & & & Ever informed about side effects of method & 69.2 & 65.4 \\
\hline Rural & 16.2 & 32.0 & & & \\
\hline \multirow[t]{2}{*}{ Urban } & 83.8 & 68.0 & Experience with side effects & & \\
\hline & & & Had side effects during study period** & 89.7 & 69.9 \\
\hline \multicolumn{2}{|l|}{ Monthly household income } & & Had two or more side effects during & & \\
\hline Lower & 45.3 & 55.1 & study period** & 60.7 & 41.7 \\
\hline Middle & 29.9 & 25.0 & Abdominal pain** & 23.9 & 11.5 \\
\hline \multirow[t]{2}{*}{ Higher } & 24.8 & 19.9 & Amenorrheat & 18.8 & 28.2 \\
\hline & & & Dizziness & 18.8 & 18.6 \\
\hline \multicolumn{2}{|l|}{ Fertility desire ${ }^{* *}$} & & Headaches & 30.8 & 29.5 \\
\hline Wants a(nother) child in $\leq 2$ yrs. & 6.8 & 19.2 & Heavy bleeding* & 30.8 & 18.0 \\
\hline \multirow{2}{*}{$\begin{array}{l}\text { Wants a(nother) child in }>2 \text { yrs. or } \\
\text { doesn't know when }\end{array}$} & & & Weight gain & 20.5 & 14.1 \\
\hline & 55.6 & 39.1 & Side effects interfered with daily activities** & * 54.7 & 35.3 \\
\hline \multirow{3}{*}{$\begin{array}{l}\text { Wants no more children } \\
\text { Undecided }\end{array}$} & 28.2 & 35.9 & Side effects interfered with relationship & & \\
\hline & 9.4 & 5.6 & with partner** & 41.0 & 23.7 \\
\hline & & & Self-medicated or took home remedies & 23.1 & 20.5 \\
\hline \multicolumn{2}{|l|}{ Method used at baseline* } & & Sought help from clinic or health worker** & 55.6 & 28.2 \\
\hline IUD & 20.5 & 9.6 & & & \\
\hline \multirow{3}{*}{$\begin{array}{l}\text { Injectable } \\
\text { Pills }\end{array}$} & 73.5 & 80.8 & Communication with others & & \\
\hline & 6.0 & 9.6 & about side effects & & \\
\hline & & & $\geq 2$ people ${ }^{* *}$ & 57.3 & 32.1 \\
\hline Length of method use at baseline** & & & Partner** & 63.3 & 37.2 \\
\hline$>1$ year & 15.4 & 36.5 & Family members & 35.0 & 26.3 \\
\hline$\leq 1$ year & 23.1 & 16.7 & Friendst & 18.0 & 10.9 \\
\hline New to method & 61.5 & 46.8 & Health worker** & 48.8 & 26.9 \\
\hline
\end{tabular}

\section{RESULTS}

A total of 273 women (41\%) from the full panel sample discontinued their baseline method during the 12 months of the study. Table 1 presents characteristics of the full sample by whether they continued their baseline method throughout the 12-month study period or discontinued contraceptive use for at least one month. The two groups of women differed significantly in the proportions who were not currently in a union (7\% of continuers vs. $16 \%$ of discontinuers) or who used the injectable at baseline (69\% vs. $78 \%)$.

Of the 273 discontinuers, 117 switched to another method and 156 stopped contraceptive use for one month or more (Table 2). Compared with stoppers, women who switched tended to be younger and more highly educated; they also were more likely to be in union ( $90 \%$ vs. $80 \%$ ), urban ( $84 \%$ vs. $68 \%$ ) and of lower parity (55\% vs. $42 \%$ ). Switchers were also more likely than stoppers to be using the IUD and less likely to be using the injectable at baseline, to be new method users ( $62 \%$ vs. $47 \%$ ), to have discussed discontinuing with their partner prior to doing so ( $86 \%$ vs. $60 \%$ ) and to have discontinued because of problems with the method ( $88 \%$ vs. $49 \%$ ). A greater percentage of switchers than stoppers experienced side effects (90\% vs. 70\%), including side effects that interfered with daily activities (55\% vs. 35\%) or the relationship with their partner (41\% vs. $24 \%$ ). Also, a significantly greater percentage of switchers than stoppers discussed these side effects with two or more people (57\% vs. $32 \%$ ), their partner $(63 \%$ vs. $37 \%)$ or a health worker ( $49 \%$ vs. $27 \%)$. Among women who switched, $37 \%$ chose the pill, $21 \%$ an injectable and 14\% the IUD; 14\% chose traditional methods and 13\%, condoms (not shown).

An additional descriptive analysis of the attitudes and behaviors of discontinuers, by type of side effect, revealed significant differences in health-seeking behaviors, dis- 
TABLE 3. Among women who switched or stopped, percentage who reported selected reactions to contraceptive side effects, by side effect 2006-2007

\begin{tabular}{|c|c|c|c|c|c|c|}
\hline \multirow[b]{2}{*}{ Reaction } & \multicolumn{2}{|l|}{ Headache } & \multicolumn{2}{|c|}{ Amenorrhea } & \multicolumn{2}{|c|}{ Heavy Bleeding } \\
\hline & $\begin{array}{l}\text { Switched } \\
(\mathrm{N}=36)\end{array}$ & $\begin{array}{l}\text { Stopped } \\
(\mathrm{N}=46)\end{array}$ & $\begin{array}{l}\text { Switched } \\
(\mathrm{N}=22)\end{array}$ & $\begin{array}{l}\text { Stopped } \\
(\mathrm{N}=44)\end{array}$ & $\begin{array}{l}\text { Switched } \\
(N=36)\end{array}$ & $\begin{array}{l}\text { Stopped } \\
(\mathrm{N}=28)\end{array}$ \\
\hline $\begin{array}{c}\text { Side effects interfered } \\
\text { with daily activities }\end{array}$ & 66.7 & 71.7 & 59.1 & 43.2 & 75.0 & 75.0 \\
\hline $\begin{array}{l}\text { Side effects interfered with } \\
\text { relationship with partner }\end{array}$ & 41.7 & 47.8 & 27.3 & 20.5 & 72.2 & 71.4 \\
\hline $\begin{array}{l}\text { Self-medicated or } \\
\text { took home remedies }\end{array}$ & $36.1 \dagger$ & 56.5 & $13.6+$ & 34.1 & 19.4 & 21.4 \\
\hline $\begin{array}{l}\text { Sought help from } \\
\text { clinic or health worker }\end{array}$ & 58.3 & 45.7 & $63.6^{*}$ & 36.4 & 72.2 & 57.1 \\
\hline $\begin{array}{l}\text { Discussed side effects } \\
\text { with } \geq 2 \text { people }\end{array}$ & 94.4 & 89.1 & $95.5+$ & 79.6 & $100.0^{*}$ & 85.7 \\
\hline $\begin{array}{l}\text { Discussed side effects } \\
\text { with partner }\end{array}$ & 69.4 & 63.0 & 68.2 & 50.0 & $80.6^{* *}$ & 46.4 \\
\hline $\begin{array}{l}\text { Discussed side effects } \\
\text { with family members }\end{array}$ & 33.3 & 43.5 & 40.9 & 31.8 & 38.9 & 42.9 \\
\hline $\begin{array}{l}\text { Discussed side effects } \\
\text { with friends }\end{array}$ & 19.4 & 15.2 & 9.1 & 9.1 & 19.4 & 25.0 \\
\hline $\begin{array}{l}\text { Discussed discontinuing } \\
\text { baseline method with } \\
\text { partner before doing so }\end{array}$ & $88.9^{*}$ & 69.6 & | 90.9 & 77.3 & $97.2^{* *}$ & 67.9 \\
\hline
\end{tabular}

${ }^{*} \mathrm{p}<.05 .{ }^{* *} \mathrm{p}<.01 .+\mathrm{p}<0.1$ area of residence remained significant, indicating that among women in urban areas, the odds of switching instead of stopping were almost 2.6 times as high as the odds among women in rural areas. Compared with women who had used a method for more than a year, those who had used a method for a year or less were significantly more likely to have switched than to have stopped (odds ratio, 3.5). As in the bivariate analysis, experiencing amenorrhea was associated with a reduced risk of switching methods (0.3). However, heavy bleeding, which was associated with switching in the bivariate analysis, lost significance in the multivariate analysis. Women who sought help with side effects from a clinic or health worker and who discussed discontinuing a method with their partner before doing so were also significantly more likely to have switched to another method than to have stopped (2.0 and 3.2, respectively). And, women who discontinued their baseline method because of problems with it were more likely to switch than were women who discontinued because of reduced need or for other reasons (6.1).

\section{DISCUSSION}

Contraceptive discontinuation was common in the study population: More than four out of 10 women quit using their baseline method within the 12-month study period. However, $43 \%$ of these women switched to another method within a month. In a comparison of switchers and stoppers, we found significant differences in demographic characteristics, experience of side effects, discussion of discontinuation and main reason for discontinuation.

The study had some limitations. For example, right and left censoring of the data marked the periods before and after the study. Also, the analysis focused on the discontinuation and what happened in the next month; as a result, additional censoring of the data due to analytic constraints occurred. For instance, switchers may have used a new method for only a single month or in the index month immediately following discontinuation of the baseline method. Similarly, stoppers may have resumed use of the same or another method after a lapse of one month or more, in effect becoming switchers. A larger study population and a longer period of observation could address some of these issues.

In the literature, switching is assessed for the first three months after discontinuation, even though pregnancy could occur during this period. ${ }^{3}$ However, assessing switching for just one month may not produce fewer significant results. Research from the 2002 U.S. National Survey of Family Growth found that most switching occurs in the first month after discontinuation; the probability of resuming contraceptive use after discontinuation was $72 \%$ in the first month, and reached only $76 \%$ by three months. ${ }^{24}$

Another limitation of the analysis is its assessment of switching behavior rather than duration of contraceptive use. A woman who discontinued her baseline method early in the study period could have switched to-and sub- 
TABLE 4. Odds ratios of method switching versus stopping from multivariate logistic regression, according to selected characteristics, Honduras, 2006-2007 ( $N=270)$

Variable

OR

\section{Age}

$15-24$

$25-34$

35-44

Education

None

Primary

$\geq$ secondary

No. of children ever born

$0-1$

$\geq 2$

Residence

Rural (ref)

Urban*

$2.58(1.17-5.68)$

\section{Fertility desire}

Wants a(nother) child in $\leq 2 \mathrm{yrs}$./undecided (ref) $\quad 1.00$

Wants a(nother) child in $>2$ yrs./

doesn't know when

Wants no more children

Service quality

Provider answered all questions

Informed about advantages and

disadvantages of method

\section{Length of method use at baseline}

$>1$ year (ref)

$\leq 1$ year*

New to method $\dagger$

Method used at baseline

IUD (ref)

Injectable

Pill

Experience with side effects

Had two or more side effects

during study period

Abdominal pain

Heavy bleeding $\dagger$

Amenorrhea*

Side effects interfered with daily activities

Side effects interfered with

relationship with partner

Sought help from clinic or health worker*

Communication with others

about side effects

Friends

$1.05(0.44-2.49)$

\section{Discussed discontinuing method}

with partner before doing so*

$3.16(1.43-6.96)$

Main reason for discontinuation

Reduced need/other (ref)

Problems with method*

1.00

$6.05(2.68-13.66)$

Pseudo R2

0.29

Log likelihood

$-129.91$

${ }^{*} p<.05 .{ }^{* *} p<.01 .+p<0.1$. Note: Three switchers with missing information on main reason for discontinuation were dropped from the analysis.

sequently discontinued-another method; therefore, she may have had fewer months of contraceptive use than a woman who discontinued at month 11 without adopting another method. Data from only 12 months does not allow for close examination of contraceptive use, though we do know that the mean time until discontinuation of the baseline method was comparable for the two groups of women: 6.0 months for switchers and 6.4 months for stoppers. Finally, the influence of side effects and related behaviors on discontinuation may be affected by the inclusion of women with no side effects in the reference group for these variables.

Despite these limitations, the study yielded interesting findings. Multivariate analysis showed that women living in urban areas were more likely to be switchers than stoppers, possibly because more urban than rural women used IUDs, which require an active decision and a clinic visit to discontinue. Urban women also have easier access to family planning services, including a more diverse supply of methods and providers. Conversely, limited access to services, as well as a lack of encouragement to seek help for side effects from a clinic or health worker, may reduce method switching.

Of all variables related to side effects, seeking help from a health clinic was most strongly related to method switching. Though side effects may lead to method discontinuation, their relationship with subsequent use is less clear. According to our findings, only amenorrhea was negatively associated with switching. This suggests that amenorrhea discourages the immediate uptake of new methods. Formative qualitative work in Honduras with current and previous users of contraceptives indicates that amenorrheic women discontinue for two main reasons: to determine their pregnancy status and to reestablish regular menstrual patterns. In our study, amenorrhea was most common among injectable users. These findings suggest an opportunity for providers to teach women about amenorrhea during initiation of the injectable and to discuss the adoption of nonhormonal barrier methods with women who otherwise may take a break from contraception to determine if they are pregnant.

Finally, the study found an association between switching and discussing discontinuation with a partner before deciding to discontinue. The study did not, however, determine what it is about discussions with a partner (or others) that supports switching behavior. Do discussions reinforce a woman's decision to use family planning and encourage her to try a different method (i.e., the quality of the discussion)? Or do discussions represent supportive relationships and being able to confide troubles and discuss family planning options with a partner or spouse or others (i.e., the quality of the relationship)?

Answers to these questions are beyond the scope of the present research, yet point to avenues for further investigation. In the meantime, our findings underscore the need for Honduran family planning programs to provide women with a full array of contraceptive methods and providers, ensuring that all women have access to services that support contraceptive continuation. Our findings also suggest that Honduran family planning programs, in their effort to support women's continuing contraceptive use, 
should encourage them to talk with their partners, family and others about stopping or switching methods before making-and acting on-a decision.

\section{REFERENCES}

1. Vadnais D, Kols A and Abderrahim N, Women's Lives and Experiences: Changes in the Past Ten Years, Calverton, MD, USA: ORC Macro, 2006

2. Bradley SEK, Schwandt HM and Khan S, Levels, trends, and reasons for contraceptive discontinuation, DHS Analytical Studies, Calverton, MD, USA: ICF Macro, 2009, No. 20.

3. Ali M and Cleland J, Oral contraceptive discontinuation and its aftermath in 19 developing countries, Contraception, 2010, 81(1):22-29.

4. Ali M and Cleland J, Determinants of contraceptive discontinuation in six developing countries, Journal of Biosocial Science, 1999, 31(3):343-360.

5. Curtis SL and Blanc AK, Determinants of Contraceptive Failure, Switching, and Discontinuation: An Analysis of DHS Contraceptive Histories, Calverton, MD, USA: Macro International, Inc., 1997.

6. United Nations Department of Economic and Social Affairs, Levels and Trends of Contraceptive Use as Assessed in 2002, New York: United Nations, 2006.

7. Barden-O'Fallon JL, Speizer LS and White J, The association between contraceptive discontinuation and pregnancy intentions in Guatemala, Revista Panamericana de Salud Publica, 2008, 23(6):410-417.

8. Conde-Agudelo A, Rosas-Bermúdez A and Kafury-Goeta AC, Birth spacing and risk of adverse perinatal outcomes: a meta-analysis, Journal of the American Medical Association, 2006, 295(15):1809-1823.

9. Davidson AR et al., Injectable contraceptive discontinuation and subsequent unintended pregnancy among low-income women, American Journal of Public Health, 1997, 87(9):1532.

10. Leite IC and Gupta N, Assessing regional differences in contraceptive discontinuation, failure and switching in Brazil, Reproductive Health, 2007, <http://www.reproductive-health-journal.com/content/ pdf/1742-4755-4-6.pdf>, accessed July 20, 2007.

11. Do M and Koenig MA, Effect of family planning services on modern contraceptive method continuation in Vietnam, Journal of Biosocial Science, 2007, 39(2):201-220.

12. Jain AK, Fertility reduction and the quality of family planning services, Studies in Family Planning, 1989, 20(1):1-16.

13. Blanc AK, Curtis SL and Croft TN, Monitoring contraceptive continuation: links to fertility outcomes and quality of care, Studies in Family Planning, 2002, 33(2):127-140

14. Ali M and Cleland J, Contraceptive discontinuation in six developing countries: a cause-specific analysis, International Family Planning Perspectives, 1995, 64(3):92-97.

15. Rosenburg MJ, Waugh MS and Meehan TE, Use and misuse of oral contraceptives: risk indicators for poor pill taking and discontinuation, Contraception, 1995, 51(5):283-288.

16. Khan M, Factors associated with oral contraceptive discontinuation in rural Bangladesh, Health Policy and Planning, 2003, 18(1):101108.

17. Halpern V et al., Strategies to improve adherence and acceptability of hormonal methods for contraception, Cochrane Database of Systematic Reviews, 2006, 25(1):CD004317.

18. Koenig MA, Hossain MB and Whittaker M, The influence of quality of care upon contraceptive use in rural Bangladesh, Studies in Family Planning, 1997, 28(4):278-289.

19. Steele F, Curtis $S$ and Choe M, The impact of family planning service provision on contraceptive-use dynamics in Morocco, Studies in Family Planning, 1999, 30(1):28-42.

20. León FR et al., One-year client impacts of quality of care improvements achieved in Peru, FRONTIERS Final Report, Washington, DC: Population Council, 2003.
21. RamaRao $S$ et al., The link between quality of care and contraceptive use, International Family Planning Perspectives, 2003, 29(2):76-83.

22. Hossain MB, Analyzing the relationship between family planning workers' contact and contraceptive switching in rural Bangladesh using multilevel modeling, Journal of Biosocial Science, 2005, 37(5): $529-554$

23. Secretaría de Salud, Honduras (SS), Instituto Nacional de Estadística (INE) and Macro International, Encuesta Nacional de Salud y Demografia 2005-2006, Tegucigalpa, Honduras: SS, INE and Macro International, 2006

24. Vaughan B et al., Discontinuation and resumption of contraceptive use: results from the 2002 National Survey of Family Growth, Contraception, 2008, 78(4):271-283.

\section{RESUMEN}

Contexto: Descontinuar el uso de anticonceptivos contribuye a embarazos no planeados y a nacimientos no deseados; también está relacionado a niveles mayores de morbilidad y mortalidad maternas, neonatales e infantiles. Sería útil para los programas dirigidos a prevenir los embarazos no planeados y sus consecuencias, contar con información sobre las diferencias entre las mujeres que dejan de usar su método anticonceptivo por largo tiempo, y aquellas que cambian a otro método en seguida.

Métodos: Los datos provienen de dos rondas de entrevistas con mujeres en edades de 15-44 años. Para la primera ronda, se entrevistaron a 800 usuarias nuevas o de larga experiencia de anticonceptivos tales como los inyectables, la píldora o el DIU. Para la segunda ronda, se entrevistaron a 671 de estas mujeres un año después. Usando análisis bivariado, se examinaron las asociaciones entre las actitudes y conductas de las mujeres que descontinuaron su método y los efectos secundarios que experimentaron. Con análisis de regresión logística multivariada, se analizaron las diferencias entre las mujeres que adoptaron un nuevo método inmediatamente o dentro del lapso de un mes; y aquellas que no usaron ningún anticonceptivo por lo menos un mes después de discontinuar.

Resultados: De las 671 mujeres que participaron en la entrevistada de seguimiento, 41\% (273) descontinuaron el uso de su método anticonceptivo dentro del año de seguimiento; de ellas, 43\% (117) cambiaron a un nuevo método dentro de un mes de haber discontinuado, y 57\% (156) no reiniciaron el uso después de un lapso de un mes o más. La búsqueda de ayuda de un trabajador de salud para manejar los efectos secundarios, la residencia urbana, el hablar con la pareja sobre la decisión de descontinuar, y haber recién adoptado un nuevo método en el momento de la entrevista de línea de basa, se asociaron con mayores probabilidades de cambiar a otro método (razones de momios, 2.0-3.5).

Conclusión: El acceso a servicios de planificación familiar de alta calidad y el diálogo con las parejas y familias antes de interrumpir el uso de anticonceptivos, son importantes para las mujeres que experimentan efectos secundarios y que están en riesgo de descontinuar el uso anticonceptivo.

\section{RÉSUMÉ}

Contexte: L'arrêt de la contraception contribue aux grossesses non planifiées, aux naissances non désirées et à une morbidi- 
té et mortalité maternelles, néonatales et infantiles accrues. Il serait utile aux programmes qui cherchent à prévenir les grossesses non planifiées et leurs conséquences de disposer d'une information sur les différences entre les femmes qui arrêtent la contraception et celles qui changent de méthode.

Méthodes: Les données proviennent de deux séries d'entretiens avec des femmes âgées de 15 à 44 ans (800 interviewées à la base et 671 réinterviewées un an plus tard) qui venaient d'adopter ou qui continuaient la pratique de la contraception injectable, de la contraception orale ou l'usage du stérilet. Les associations entre les attitudes et comportements des femmes qui avaient arrêté leur méthode de base et les effets secondaires qu'elles avaient ressentis sont examinées par analyse bivariée. Les différences entre les fermmes qui avaient changé de méthode immédiatement ou en l'espace d'un mois après l'arrêt et celles qui avaient arrêté la contraception pendant un mois ou plus sont évaluées par régression logistique multivariée.

Résultats: Des 671 femmes réinterviewées, 41\% (273) avaient arrêté leur méthode contraceptive de base durant la période de suivi d'un an; parmi elles, 43\% (117) avaient adopté une nouvelle méthode et $57 \%$ (156) avait interrompu leur pratique contraceptive pendant un mois ou plus. La recherche d'aide auprès d'un agent sanitaire concernant les effets secondaires, le lieu de résidence urbain, le dialogue avec un partenaire concernant la décision d'arrêter la méthode et la nouvelle et récente adoption d'une méthode sont associés à une probabilité accrue de changement de méthode (rapports de probabilités, 2,0-3,5). Conclusion: L'accès à des services de planification familiale de haute qualité et l'encouragement du dialogue avec les partenaires et les familles avant l'arrêt de la pratique contraceptive sont importants pour les femmes qui ressentent des effets secondaires et présentent un risque d'arrêt de leur méthode.

Author contact: bardenof@email.unc.edu 